\title{
URGENSI FORMULASI JUSTICE COLLABORATOR SEBAGAI SYARAT PEROLEHAN REMISI BAGI NARAPIDANA KORUPSI DI INDONESIA
}

\author{
Elizabeth Ghozali \\ Fakultas HukumUniversitas Katolik Santo Thomas, Medan,Indonesia \\ Email : ibethghoz@gmail.com
}

\begin{abstract}
ABSTRAK
Penelitian ini bertujuan untuk mengetahui kerangka hukum terkait justice collaborator dalam sistem hukum Indonesia selama ini dan bagaimana prospek pengaturan tentang justice collaborator dalam pemberian remisi bagi narapidana korupsi. Metode penelitian yang digunakan adalah yuridis normatif dengan cara mengkaji dan menganalisis data sekunder yang berkaitan dengan kebijakan tentang justice collaborator dan pemberian remisi bagi narapidana pelaku tindak pidana korupsi, kemudian mengelaborasi pengaturan justice collaborator di negara lain sebagai bahan perbandingan dengan menggunakan metode analisis yang mengarah kepada pendekatan futuristik. Hasil penelitian menunjukkan bahwa kerangka hukum terkait justice collaborator dalam tindak pidana korupsi belum mendapatkan pengaturan yang memadai sebagai landasan hukum bagi aparat penegak hukum untuk memberikan perlindungan maksimal kepada justice collaborator, dan prospek pengaturan terhadap justice collaborator berkaitan dengan pemberian remisi narapidana korupsi di Indonesia pada masa mendatang memiliki peluang yang besar mengingat peranannya yang sangat strategis dalam mengungkap jaringan tindak pidana korupsi yang terorganisir.
\end{abstract}

Kunci : justice collaborator, korupsi, remisi, perlindungan, narapidana

\begin{abstract}
This study aims to determine the legal framework related to "justice collaborators" in the Indonesian legal system so far and how the prospects for the regulation of "justice collaborators" in providing remissions for prisoner's corruption convicts. The research method used is juridical normative by reviewing and analyzing secondary data related to policies on "justice collaborators" and giving remissions to convicts who are perpetrators of corruption, then elaborating on justice collaborator arrangements in other countries as a comparison using analytical methods that lead to the approach. futuristic. The results show that the legal framework related to "justice collaborators" in criminal acts of corruption has not received adequate regulation as a legal basis for law enforcement officers to provide maximum protection to "justice collaborators" and the prospect of regulating "justice collaborators" in connection with the remission of corruption convicts in Indonesia in the future. has a great opportunity given its very strategic role in exposing organized corruption criminal networks.
\end{abstract}

Keywords : justice collaborator, corruption, remission, protection, prison

\section{A. PENDAhuluan}

Berdasarkan Pasal 1 ayat (3) UUD

Negara Republik Indonesia Tahun 1945. Indonesia adalah negara hukum (rechtstaat atau rule of law). Namun pada kenyataannya, apa yang diidealkan (das sollen) tidak selalu sesuai dengan realita yang terjadi dalam masyarakat (das sein). Data Indonesia Corruption Watch (ICW) selama semester pertama

Urgensi Formulasi Justice Collaborator Sebagai Syarat Perolehan Remisi Bagi Narapidana Korupsi di Indonesia

Oleh : Dr. Elizabeth Ghozali, S.H., M.Hum 
2012, menunjukkan penurunan kasus korupsi dari 436 kasus dengan jumlah tersangka 1.053 orang dan kerugian negara sebesar $\mathrm{Rp} 2,1$ triliun pada periode yang sama di tahun 2011, menjadi 285 kasus korupsi dengan jumlah tersangka 597 orang dan kerugian negara hingga $\mathrm{Rp}$ 1,22 triliun. ${ }^{1}$ Namun berdasarkan survey Transparency International peringkat korupsi Indonesia untuk tahun 2012 tetap lebih buruk dari negara Asia Tenggara lainnya. ${ }^{2}$ Hal ini berarti, kondisi buruk korupsi di Indonesia masih belum banyak berubah dari tahun ke tahun. Peningkatan korupsi di Indonesia kini tidak hanya terjadi dari segi kuantitas, namun kualitas korupsi di Indonesia juga semakin meningkat. Maraknya pemberitaan mengenai jualbeli perkara, mafia hukum, mafia peradilan, mafia pajak, dan makelar kasus, mengindikasikan bahwa korupsi telah menjangkiti hukum itu sendiri. Bahkan ada komentar di sebuah jurnal asing, yang mengatakan, bahwa corruption is way of life in Indonesia, yang berarti korupsi telah menjadi pandangan dan jalan kehidupan bangsa Indonesia ${ }^{3}$.

Upaya pemberantasan korupsi yang sejak era reformasi sudah dituangkan dalam berbagai peraturan perundang-undangan dirasa tidak

\footnotetext{
Elizabeth Ghozali., 2016, Kebijakan Hukum Pidana Terhadap Pemberian Remisi Bagi Narapidana Korupsi Berdasarkan Tujuan Pemasyarakatan Di Indonesia, Disertasi, Program Doktor Ilmu Hukum Pascasarjana Fakultas Hukum Universitas Andalas, Padang, hlm. 9.

2 ibid

3 Amien Rais, Pengantar dalam Edy Suandi Hamid dan Muhammad Sayuti (ed.), Menyikapi Korupsi, Kolusi dan Nepotisme di Indonesia, Aditya Media, Yogyakarta, hlm.ix, sebagaimana dikutip dari Elwi Danil., 2012, Korupsi: Konsep, Tindak Pidana dan Pemberantasannya, Rajawali Pers, Jakarta, hlm. 65
}

berjalan dengan baik dan kurang efektif. Istilah korupsi sering dikaitkan dengan ketidakjujuran atau kecurangan seseorang dalam bidang keuangan ${ }^{4}$. Atas dasar pemikiran tersebut, maka pemerintah melakukan pengetatan syarat terhadap pemberian remisi bagi narapidana korupsi sebagaimana diatur dalam Pasal 34 A Peraturan Pemerintah No. 99 Tahun 2012 tentang Perubahan Kedua Atas Peraturan Pemerintah No. 32 Tahun 1999 tentang Syarat dan Tata Cara Pelaksanaan Hak Warga Binaan Pemasyarakatan (PP No. 99 Tahun 2012) $)^{5}$. Salah satu syarat tersebut adalah bersedia bekerja sama dengan penegak hukum untuk membantu membongkar perkara tindak pidana yang dilakukannya atau disebut sebagai justice collaborator.

Justice collaborator merupakan orang yang mengungkapkan pelanggaran atau kejahatan yang turut dilakukannya. Segala bentuk pelanggaran dan kejahatan, termasuk korupsi dapat terungkap melalui peran justice collaborator. Sebagaimana dalam kasus Agus Condro ${ }^{6}$ dan Kasus Susno Duadji. ${ }^{7} \quad$ Fakta tersebut

4 Elwi Danil., 2012, Korupsi: Konsep, Tindak Pidana dan Pemberantasannya, Raja Grafindo Persada, Jakarta, hlm. 3

5 Ketentuan ini juga berlaku bagi terpidana kasus terorisme, narkotik, kejahatan terhadap keamanan negara, kejahatan hak asasi manusia yang berat, dan kejahatan transnasional terorganisasi lainnya.

6 Agus Condro, Pelaku yang Bekerjasama yang menjadi tokoh sentral untuk mengungkap skandal pemainan uang puluhan anggota DPR dalam proses pemilihan Gubernur Bank Indonesia Lihat dalam: Humas LPSK., 2012, Buku Potret Saksi dan Korban dalam Media Massa Tahun 2011, Lembaga Perlindungan Saksi dan Korban (LPSK), Jakarta, hlm. 15.

7 Susno Duadji yang mengungkapkan adanya makelar kasus dalam penyidikan kasus pajak senilai Rp.25.000.000.000,- di institusinya, yaitu Markas Besar Kepolisian Negara Republik Indonesia. Laporan Susno Duadji

Urgensi Formulasi Justice Collaborator Sebagai Syarat Perolehan Remisi Bagi Narapidana Korupsi di Indonesia

Oleh : Dr. Elizabeth Ghozali, S.H., M.Hum 
mengungkap keberadaan mafia pajak, yakni Gayus Tambunan yang mengakui bahwa dirinya telah membagikan uang sejumlah Rp. 5.000.000.000,- kepada jaksa, polisi dan hakim ${ }^{8}$. Justice collaborator memiliki peran yang sangat signifikan dalam mengungkap berbagai kasus korupsi. Namun ketentuan mengenai syarat justice collaborator dalam PP Nomor 99 Tahun 2012 khusus bagi narapidana korupsi dan bagi teroris serta narapidana narkoba dianggap terlalu dini, karena tidak ada landasan hukum perundangannya.

Berdasarkan latar belakang masalah tersebut, dicoba untuk mengangkat permasalahan sebagai upaya untuk mengetahui kerangka hukum terkait justice collaborator dalam sistem hukum Indonesia selama ini dan bagaimana konsep dan pengaturan tentang justice collaborator dalam pemberian remisi bagi narapidana korupsi.

\section{B. METODE PENELITIAN}

Penelitian ini merupakan penelitian hukum normatif, yaitu penelitian yang dilakukan dengan cara meneliti bahan pustaka atau data sekunder yang meliputi bahan hukum primer, bahan hukum sekunder dan bahan hukum tertier ${ }^{9}$, yaitu mengkaji dan menganalisis berbagai data

kemudian berhasil mengungkap keberadaan mafia pajak, yakni Gayus Tambunan, ibid, hlm. 18.

8 Kompas, Kedudukan "Whistle Blower" Perlu Diperkuat, diakses dari http://cetak.kompas. com/read/2010/06/08/02592451/kedudukan. whistle.blower.perlu.diperkuat

9 Soerjono Soekanto dan Sri Mamudji., 1985, Penelitian Hukum Normatif, Suatu Tinjauan Singkat, Penerbit Rajawali, Jakarta, hlm, 14 - 15, dan lihat juga dalam Ronny Hanitijo Soemitro., 1995, Metodologi Penelitian Hukum dan Jurimetri, Ghalia Indonesia, Jakarta, hlm $24-25$. sekunder yang berkaitan dengan kebijakan tentang justice collaborator dan pemberian remisi bagi narapidana khususnya pelaku tindak pidana korupsi.

Data yang diperoleh kemudian diolah menggunakan metode analisis kualitatif dan komparatif dalam mengelaborasi pengaturan justice collaborator di negara lain sebagai bahan perbandingan dan pembelajaran bagi Indonesia dan juga metode analisis yang mengarah kepada pendekatan futuristik ${ }^{10}$.

\section{HASIL PENELITIAN DAN PEMBAHASAN \\ 1. Kerangka hukum terkait justice collaborator}

Perlindungan hukum justice collaborator di Indonesia masih sangat lemah. Hal ini dapat dilihat dari segi: pertama, permasalahan riil yang menunjukkan kenyataan bahwa justice collaborator tidak mendapatkan penghargaan dan perlindungan, bahkan turut dijadikan tersangka atas kasus korupsi yang dilaporkannya; dan kedua, permasalahan materil dan formil dalam berbagai peraturan.

Justice collaborator memiliki peranan yang sangat dominan dan strategis dalam membantu aparat penegak hukum untuk membongkar dan mengungkap tindak pidana. Hal itu dikarenakan, seorang Justice collaborator adalah orang yang ikut berperan dalam terjadinya suatu tindak pidana terorganisir dan dilakukan secara berjamaah seperti tindak pidana korupsi. Namun posisi seorang Justice collaborator bukan merupakan pelaku utama dari terjadinya suatu tindak pidana korupsi. Orang yang demikian tersebut dapat dijadikan sumber

10 Sunaryati Hartono., 1994, Penelitian Hukum di Indonesia Pada Akhir Abad ke 20. Alumni, Bandung, hlm. 130.

Urgensi Formulasi Justice Collaborator Sebagai Syarat Perolehan Remisi Bagi Narapidana

Korupsi di Indonesia

Oleh : Dr. Elizabeth Ghozali, S.H., M.Hum 
informasi dalam kaitannya dengan adanya tersangka dan alat bukti lain dalam tindak pidana korupsi yang belum ditemukan oleh penegak hukum. Justice collaborator sering digunakan untuk mengungkap ketidakjujuran dan penyimpangan yang dilakukan oleh dirinya sendiri dan rekan-rekannya dalam suatu tindak pidana. Upaya ini tentu bukan pekerjaan yang mudah karena ia harus mengungkapkan dengan jujur apa yang telah ia lakukan dengan rekan-rekannya dalam suatu tindak pidana terorganisir yang dalam hal ini ia juga akan mendapatkan beban atas yang diungkapnya dalam kesaksian tersebut. Apabila ditinjau berdasarkan peran justice collaborator yang strategis untuk mempercepat pengungkapan tindak pidana terorganisir, maka kebutuhan akan peraturan perundang-undangan yang mengatur mengenai justice collaborator sangat diperlukan sehingga diperlukan political will yang kuat baik dari pemerintah dan DPR serta dari semua pihak yang berkepentingan untuk mengimplementasikan Justice collaborator terutama dalam kasus korupsi.

Dari tiga jenis peraturan dalam sistem hukum Indonesia yang menyinggung tentang justice collaborator ternyata belum memberikan perlindungan maksimal kepada justice collaborator. Argumentasinya sebagai berikut:

a. UU No.13 Tahun 2006 mengindikasikan bahwa, kontribusi justice collaborator hanya dijadikan pertimbangan hakim dalam meringankan pidananya. Namun, ketentuan tersebut tidak memiliki daya mengikat yang mewajibkan hakim untuk memberi keringanan pidana, sehingga tidak ada jaminan bagi justice collaborator untuk mendapat keringanan pidana. Pembentukan UU No. 13 Tahun 2006 sejak awalnya memang tidak ditujukan untuk mengatur justice collaborator. Hal ini dinyatakan oleh Harkristuti Harkrisnowo sebagai wakil Pemerintah dalam Sidang Perkara Pengujian UndangUndang Nomor 13 Tahun 2006, bahwa ${ }^{11}$ :

...Latar belakang UndangUndang Perlindungan Saksi, yang kebetulan saya sendiri yang merancang waktu itu, yang sebenarnya memang tidak ada keinginan dari perancang undangundang untuk memasukkan whistle blower ke dalam ketentuan, karena kita tahu bahwa Saksi dan whistle blower atau saya sebut sebagai pemukul kentongan bahasa Indonesianya, itu adalah 2 kelompok yang berbeda walaupun mereka samasama orang yang memberikan keterangan dalam proses peradilan... Berkaitan dengan equivalency antara Saksi dengan whistle blower. Di negara-negara yang disebut oleh para Ahli ini memang ditemukan Whistle Blower Act, tapi di negara tersebut juga ada Victim and Witness Protection Act mereka berada dalam 2 rezim hukum yang berbeda.

Putusan Mahkamah Konstitusi semakin menguatkan pernyataan bahwa UU No. 13 Tahun 2006 memang tidak

11 Risalah Sidang Perkara Nomor 42/PUUVIII/2010, 19 Agustus 2010, Perihal Permohonan Pengujian Undang-Undang Nomor 13 Tahun 2006 Tentang Perlindungan Saksi dan Korban Terhadap Undang-Undang Dasar Negara Republik Indonesia Tahun 1945.

Urgensi Formulasi Justice Collaborator Sebagai Syarat Perolehan Remisi Bagi Narapidana Korupsi di Indonesia 
ditujukan untuk mengatur justice collaborator, bahwa ${ }^{12}$ :

Mahkamah berpendapat bahwa Undang-Undang a quo memang tidak mengatur tentang whistle blower. Terkait dengan hal tersebut Mahkamah sependapat dengan keterangan Pemerintah yang menyatakan bahwa kerumitan posisi whistle blower (pemukul kentongan) tersebut menyebabkan para perumus undang-undang $\quad a \quad q u o$ memutuskan untuk tidak memasukkan tentang whistle blower.

Dengan demikian, UU No. 13 Tahun 2006 belum memberikan perlindungan hukum maksimal justice collaborator. Hal ini juga diakui oleh Mas Achmad Santosa, bahwa saksi pelaku sekaligus pengungkap adanya korupsi tidak mendapatkan perlindungan dalam sistem hukum Indonesia ${ }^{13}$. Salah satu langkah yang sedang ditempuh oleh pemerintah saat ini untuk memberikan pengaturan tentang Justice collaborator dalam peradilan pidana adalah dengan melakukan revisi terhadap UU No. 13 Tahun 2006 sesuai dengan amanat dalam ketentuan Pasal 37 UNCAC dan Pasal 26 Konvensi PBB Anti Kejahatan Transnasional yang terorganisir. Adapun revisi tersebut dilakukan dengan memasukkan kedalam Pasal 1 yang berisi tentang ketentuan umum pengertian Justice collaborator yaitu saksi/atau yang juga pelaku tindak

12 Ibid

13 Sentra Informasi dan Data untuk Anti Korupsi, "Whistle Blower" Belum Terlindung, diakses dari http://infokorupsi.com/id/korupsi.php?ac=82 35\&l=-belum-terlindung pidana yang membantu aparat penegak hukum untuk mengungkap suatu tindak pidana dan/atau pengembalian asetaset/hasil suatu tindak pidana kepada Negara dengan memberikan kesaksian atau informasi lain. Selain itu, dalam draft revisi UU No. 13 Tahun 2006 tersebut juga memasukan ketentuan-ketentuan yang memberikan perlakuan khusus terhadap Justice collaborator berkaitan dengan perlindungan keamanan selama dalam proses peradilan hingga penjatuhan vonis dan pelaksanaan pidana berupa pemisahan tempat tahanan dan penjara yang berjauhan dengan tersangka/narapidana lain yang diungkap, pemberkasan dengan tersangka/terdakwa lain yang diungkapnya, penundaan penuntutan atas tidak pidana yang diungkapnya dengan tindak pidana yang diakuinya, serta penghargaan terhadap pelapor pelaku berupa keringanan hukuman, penghapusan penuntutan dan pemberian remisi atau grasi dengan pertimbangan khusus apabila pelapor pelaku adalah seorang narapidana.

Pengaturan baru lainnya yang terdapat dalam draft revisi UU No. 13 Tahun 2006 tersebut adalah mengenai syarat-syarat untuk dapat menentukan apakah seseorang dianggap sebagai Justice collaborator yaitu keseriusan tindak pidana yang diungkap, sifat pentingnya keterangan yang diberikan oleh pelapor pelaku, pelapor pelaku bukan pelaku utama dalam tindak pidana yang diungkapnya atau tindak pidana lain yang dilakukannya, pelapor pelaku

Urgensi Formulasi Justice Collaborator Sebagai Syarat Perolehan Remisi Bagi Narapidana Korupsi di Indonesia 
mengakui sendiri tindak pidana yang pernah ia lakukan sebelumnya yang belum pernah diperiksa dan diputus oleh pengadilan, tindak pidana lain yang dilakukannya merupakan tindak pidana yang lebih ringan dibandingkan dengan tindak pidana yang diungkapnya di mana tindak pidana lain yang dilakukannnya tidak termasuk tindak pidana pembunuhan atau kekerasan seksual, tindak pidana di mana korbannya tidak setuju dengan restitusi yang diberikan, dan tindak pidana yang mendapat tuntutan dari masyarakat agar pelapor pelaku diadili. Jika ditinjau dari substansi yang terdapat dalam draft revisi UU No. 13 Tahun 2006 di atas, maka dapat dikatakan bahwa pemerintah telah menyadari betapa pentingnya peranan Justice collaborator dalam peradilan pidana khususnya dalam mengungkap kejahatan terorganisir sehingga memerlukan adanya suatu landasan hukum yang kuat untuk memberikan perlindungan kepada Jusitice collaborator.

b. SEMA telah mengatur lebih lanjut mengenai kriteria serta mekanisme penanganan perkara yang melibatkan justice collaborator. Namun, pada dasarnya ketentuan dalam SEMA masih memiliki banyak kelemahan dari segi materil yakni:

i. Tidak diaturnya hak dan bentuk perlindungan bagi justice collaborator;

ii. Ketentuan keringanan pidana bagi justice collaborator hanya dijadikan pertimbangan hakim dan tidak memiliki daya mengikat yang mewajibkan hakim untuk memberi keringanan pidana.

c. Peraturan Bersama sudah cukup komprehensif dalam mengatur hak dan bentuk perlindungan hukum justice collaborator. Namun, Peraturan Bersama ini masih memiliki kelemahan dari segi materil yakni:

i. Tidak diatur perlindungan maksimal bagi justice collaborator berupa penghapusan tuntutan atas tindak pidana yang dilakukannya;

ii. Keringanan pidana bagi justice collaborator hanya dijadikan pertimbangan Jaksa Agung atau Pimpinan KPK dan tidak memiliki daya mengikat yang mewajibkan Jaksa Agung atau Pimpinan KPK untuk memberi penghargaan berupa keringanan pidana;

iii. Tidak diatur secara jelas mengenai hubungan kolaborasi dan koordinasi antar penegak hukum dalam memberikan perlindungan bagi justice collaborator.

Di samping itu, Peraturan Bersama juga memiliki kelemahan dari segi formil yakni lingkup keberlakuan tidak mengikat bagi hakim di lingkungan Mahkamah Agung. Peraturan Bersama ini hanya mengikat LPSK, KPK, Kejaksaan Agung, Kepolisian, dan Kementerian Hukum dan HAM. Padahal perlindungan justice collaborator idealnya harus melibatkan seluruh instansi penegak hukum.

Dari argumen yang telah dikemukakan, dapat diketahui bahwa di antara seluruh peraturan di atas, Peraturan Bersama merupakan peraturan yang paling komprehensif

Urgensi Formulasi Justice Collaborator Sebagai Syarat Perolehan Remisi Bagi Narapidana Korupsi di Indonesia 
dalam mengatur mengenai perlindungan hukum justice collaborator. Namun, Peraturan Bersama masih memiliki kelemahan terkait tidak tidak diaturnya hubungan kerjasama antar instansi penegak hukum, terutama belum dimasukkannya pihak lembaga pemasyarakatan sebagai sub sistem dari sistem peradilan pidana. Pihak lembaga pemasyarakatan sesuai dengan ketentuan PP Nomor 99 Tahun 2012 untuk dapat memberikan remisi kepada narapidana korupsi dan narapidana pelaku tindak pidana khusus lainnya, ada syarat khusus yang harus dipenuhi oleh narapidana yakni justice collaborator. Oleh karena itu, penulis menilai bahwa perlu diadakan solusi terkait aspek legislasi dalam melindungi justice collaborator pada tahap peroleh remisi di lembaga pemasyarakatan.

Fungsi remisi dapat menjadi sarana untuk menstimulasi narapidana guna meningkatkan kualitas diri sekaligus memotivasi dirinya untuk kembali memilih jalan kebenaran karena remisi hak yang diberikan ketika berkelakuan baik selama masa pembinaan. $^{14}$

\section{Konsep Kebijakan Perlindungan Bagi Justice Collaborator}

Strategi yang banyak diterapkan di negara lain - dan dianjurkan oleh beberapa konvensi internasional seperti UNCAC dan UNTOC - untuk memberi insentif bagi pelaku tindak pidana agar mau menjadi Pelaku yang Bekerjasama (membantu aparat penegak hukum mengungkap tindak pidana serius) adalah dengan memberikan penghargaan atas kerjasama yang mereka diberikan. Bentuk penghargaan yang umum diberikan dapat dibagi menjadi dua kategori: penghargaan berupa penghapusan penuntutan

\footnotetext{
14 Suharirizal, Elizabeth Ghozali, 2018, Remisi untuk Koruptor, PT Rajagrafindo Persada, Jakarta, hlm. 197..
}

terhadap yang bersangkutan dan yang tidak berupa penghapusan penuntutan seperti berupa peringanan tuntutan/hukuman, pemberian pidana percobaan/sanksi alternatif, pemberian remisi atau grasi.

Ide perlindungan justice collaborator sesungguhnya telah diamanatkan dalam Pasal 37 ayat (3) United Nations Convention Against Corruption (UNCAC) yang telah diratifikasi melalui UU No. 7 Tahun 2006, bahwa:

Setiap negara peserta wajib mempertimbangkan kemungkinan sesuai dengan prinsip-prinsip dasar hukum nasionalnya, untuk memberikan kekebalan dari penuntutan bagi orang yang memberikan kerja sama yang substansial dalam penyelidikan atau penuntutan suatu tindak pidana yang ditetapkan berdasarkan konvensi ini.

Pemberian penghargaan berupa pengurangan masa menjalankan pidana (remisi) kepada justice collaborator yang membantu aparat penegak hukum dalam mengungkap tindak pidana korupsi ini menimbulkan banyak pro dan kontra. Beberapa resistensi terhadap konsep ini didasari pada argumentasi antara lain ${ }^{15}$ :

a. Seorang yang melakukan suatu tindak pidana harus diberikan hukuman yang setimpal sesuai dengan kejahatan yang dilakukannya;

b. Dikhawatirkan akan terjadi diskriminasi terhadap pelaku

15 Abdul Haris Semendawai, Eksistensi Justice Collaborator dalam Perkara Korupsi Catatan tentang Urgensi dan Implikasi Yuridis atas Penetapannya Pada Proses Peradilan Pidana, Makalah disampaikan dalam Stadium General Fakultas Hukum Universitas Islam Indonesia (Jogjakarta, 17 April 2013)

Urgensi Formulasi Justice Collaborator Sebagai Syarat Perolehan Remisi Bagi Narapidana

Korupsi di Indonesia

Oleh : Dr. Elizabeth Ghozali, S.H., M.Hum 
pidana yang lain dengan bobot perbuatan yang sama dengan yang dilakukannya.

Argumentasi di atas merupakan pengejawantahan prinsip equality before the law dan prinsip nonimpunity. Kedua prinsip ini menyatakan bahwa semua orang berkedudukan sama di muka hukum, sehingga semua orang yang bersalah harus dihukum tanpa ada pengecualian. Oleh karena itu, prinsip ini memandang bahwa justice collaborator tidak boleh diberi remisi.

Argumen sebaliknya menyatakan bahwa remisi merupakan bagian edukasi bagi para narapidana jika berkelakuan baik. Apalagi, undangundang juga menjamin hak untuk mendapat remisi sebagaimana diatur dalam Pasal 14 ayat (1) UU No 12 Tahun 1995 tentang Pemasyarakatan. Lahirnya UU No 12 Tahun 1995 tentang Pemasyarakatan diadopsi dari ketentuan-ketentuan hukum internasional. Antara lain, ketentuan dari PBB, yakni Standard Minimum Rules for the Treatment for the Prisoners, 30 Agustus 1955 serta Basic Principles for the Treatment of Prisoners, 14 Desember 1990. Dalam Basic Principles for the Treatment of Prisoners disebutkan bahwa semua narapidana harus diperlakukan dengan rasa penghormatan yang tinggi karena martabat yang melekat dan nilainya sebagai manusia. Selanjutnya disebutkan bahwa tidak akan ada diskriminasi atas dasar ras, warna, jenis kelamin, bahasa, agama, pendapat opini atau pendapat lainnya, asal-usul nasional atau sosial, kekayaan atau status lainnya. Oleh karena itu, remisi merupakan hak narapidana atas kewajiban yang telah dilakukannya, sehingga layak untuk didapatkan oleh narapidana.

Terhadap kedua argumen tersebut diatas dapat dijelaskan bahwa, dalam perkembangan hukum pidana kini dikenal konsep restorative justice yang mampu menjadi sandingan prinsip equality before the law dan non impunity. Konsep restorative justice menyatakan bahwa, tidak semua orang harus diperlakukan sama karena ada hal-hal yang membedakan orang tersebut dengan orang lain, sehingga atas perbedaannya itulah seseorang dapat saja tidak dipidana asalkan bertanggung jawab untuk memulihkan kerugian yang diakibatkannya. Dalam hal ini, konsep restorative justice sangat tepat diterapkan untuk melindungi justice collaborator dengan argumentasi sebagai berikut:

Justice collaborator dapat diartikan sebagai individu yang melaporkan kejahatan yang turut dilakukannya. Sebagai pihak yang terlibat dalam suatu kejahatan, justice collaborator dapat menyediakan bukti penting mengenai siapa yang terlibat dalam kejahatan itu, apa peran masingmasing pelaku, bagaimana kejahatan itu dilakukan, dan dimana bukti lainnya dapat ditemukan. Adapun upaya untuk membujuk para orang dalam agar mau bekerjasama dalam penyidikan dan penuntutan terhadap pelaku lainnya dalam tindak kriminal tersebut, para penuntut di berbagai negara menggunakan beberapa jenis perangkat hukum. ${ }^{16}$

a. Konsep restorative justice berlandaskan pada asas ketidaksamaan sebagai keadilan. Kontribusi yang diberikan oleh justice collaborator dalam mengungkap kasus korupsi ini dijadikan dasar yang membedakannya dengan koruptor biasa. Sehingga, kontribusinya ini

16 Jaringan Advokasi untuk Whistleblower, Mengadili Whistleblower, diakses dari http://elsam. or.id/catatan_hukum_revisi.doc

Urgensi Formulasi Justice Collaborator Sebagai Syarat Perolehan Remisi Bagi Narapidana

Korupsi di Indonesia

Oleh : Dr. Elizabeth Ghozali, S.H., M.Hum 
menjadi dasar untuk memperoleh remisi;

b. Konsep restorative justice akan menimbulkan efek positif bagi masyarakat dimana pihak-pihak yang potensial menjadi justice collaborator tidak akan takut lagi untuk mengungkap dan dengan demikian, kasus-kasus korupsi akan terungkap dalam jumlah yang masif.

Berdasarkan pemikiran di atas, maka konsep restorative justice yang bertujuan untuk memulihkan kerugian yang diderita oleh korban ini sangat tepat untuk diterapkan terhadap justice collaborator, sebab:

a. Justice collaborator telah membantu mengungkapkan kasus korupsi yang dilakukannya. Laporannya tersebut merupakan kontribusi yang sangat besar dalam membantu upaya pemberantasan korupsi;

b. Pemberian remisi atas justice collaborator akan menyebabkan para pihak mengungkapkan kasus korupsi yang dilakukannya. Sehingga, kasus korupsi akan terbongkar secara masif dan signifikan;

Agus Condro melaporkan kepada Komisi Pemberantasan Korupsi (KPK) mengenai dugaan suap cek pelawat (travel cheque) bagi anggota DPR periode 2004-2009, saat pemilihan Miranda Goeltom menjadi Deputi Gubernur Senior Bank Indonesia pada tahun 2004. Agus Condro juga mengakui bahwa dirinya menerima cek pelawat tersebut. Atas laporan yang disampaikan oleh Agus Condro tersebut, KPK sudah menetapkan 24 anggota DPR sebagai tersangka, termasuk Agus Condro.

Pengertian di atas pada dasarnya sejalan dengan pengertian menurut Council of Europe Committee of
Minister, bahwa yang dimaksud dengan collaborator of justice adalah: ${ }^{17}$

Seseorang yang juga berperan sebagai pelaku tindak pidana, atau secara meyakinkan adalah merupakan bagian dari tindak pidana yang dilakukan secara bersama-sama atau kejahatan terorganisir dalam segala bentuknya, atau merupakan bagian dari kejahatan terorganisir, namun yang bersangkutan bersedia untuk bekerjasama dengan aparat penegak hukum untuk memberikan kesaksian mengenai suatu tindak pidana yang dilakukan bersamasama atau terorganisir, atau mengenai berbagai bentuk tindak pidana yang terkait dengan kejahatan terorganisir maupun kejahatan serius lainnya.

Dalam hal ini, tanggung jawab yang dimiliki oleh justice collaborator terdiri atas tanggung jawab untuk mengembalikan uang negara yang dikorupsi dan tanggung jawab untuk bekerja sama dengan aparat penegak hukum untuk membongkar kasus korupsi yang dilaporkannya hingga ke akar-akarnya. Konsep ini merupakan upaya pemulihan kerugian yang diderita oleh negara akibat korupsi. Tanggung jawab justice collaborator dalam hal merestorasi kerugian negara inilah yang menggantikan pemidanaan bagi justice collaborator dalam bentuk pemberian remisi.

Jika kembali kepada esensi politik hukum pidana itu sendiri yang berarti usaha mewujudkan peraturan perundang-undangan pidana yang sesuai dengan keadaan dan situasi pada

17 Abdul Haris Semendawai, Penanganan dan Perlindungan 'Justice Collaborator' dalam Sistem Hukum Pidana di Indonesia, diakses dari

http://www.elsam.or.id/downloads/1308812 895 penanganan_dan_perlindungan_justic e_collaborator_.pdf

Urgensi Formulasi Justice Collaborator Sebagai Syarat Perolehan Remisi Bagi Narapidana

Korupsi di Indonesia

Oleh : Dr. Elizabeth Ghozali, S.H., M.Hum 
suatu waktu dan untuk masa-masa yang akan datang. Dengan kata lain bahwa politik hukum pidana berusaha meneliti perubahan-perubahan yang terjadi untuk dapat merumuskan kembali peraturan perundang-undangan saat ini (Ius constitutum) menuju peraturan perundang-undangan masa mendatang (Ius constituendum) sehingga peraturan tersebut dapat berdayaguna dan berlaku secara efektif sesuai dengan tujuan yang diharapkan. Oleh karena itu, perlu dirumuskan kembali definisi Justice collaborator itu sendiri, sehingga tidak terjadi multi tafsir dalam penerapannya oleh aparat penegak hukum.

Dengan demikian, dalam rangka pembaruan hukum pidana Indonesia berkaitan dengan pengaturan Justice collaborator perlu dikaji dengan baik dan cermat dengan meninjau kembali hakikat keberadaan dan peranan Justice collaborator dalam peradilan pidana untuk dapat merumuskan menjadi suatu kebijakan hukum pidana yang baik, sehingga politik hukum pidana berkaitan dengan Justice collaborator dalam peradilan pidana khususnya tindak pidana korupsi dapat mencapai sasaran yang diinginkan guna memberantas tindak pidana korupsi dalam rangka mewujudkan masyarakat Indonesia yang adil, makmur dan sejahtera.

\section{KESIMPULAN DAN SARAN}

Setelah dilakukan analisis terhadap permasalahan yang diajukan dalam penelitian ini, maka dapat ditarik kesimpulan sebagai berikut :

1. Kebijakan hukum pidana saat ini terhadap Justice collaborator tindak pidana korupsi di Indonesia belum mendapatkan pengaturan yang memadai untuk menjadi landasan hukum bagi aparat penegak hukum. Hingga saat ini ada tiga jenis peraturan dalam sistem hukum
Indonesia yang menyinggung tentang justice collaborator,yaitu Undang-Undang Nomor 13 Tahun 2006 tentang Perlindungan Saksi dan Korban, Surat Edaran Mahkamah Agung Nomor 4 Tahun 2011 tentang Perlakuan bagi Pelapor Tindak Pidana (Whistleblower) dan Saksi Pelaku yang Bekerjasama (Justice Collaborator) di dalam Perkara Tindak Pidana Tertentu serta Peraturan Bersama Menteri Hukum dan HAM, Jaksa Agung, Kepala Kepolisian, Komisi Pemberantasan Korupsi, Ketua Lembaga Perlindungan Saksi dan Korban tentang Perlindungan bagi Pelapor, Saksi Pelapor dan Saksi Pelaku yang Bekerjasama, namun ternyata belum memberikan perlindungan maksimal kepada justice collaborator.

2. Prospek pengaturan terhadap Justice collaborator berkaitan dengan pemberian remisi narapidana korupsi di Indonesia pada masa mendatang memiliki peluang yang besar mengingat peranannya yang sangat strategis dalam mengungkap jaringan tindak pidana korupsi yang terorganisir. Langkah yang ditempuh pemerintah saat ini yaitu dengan melakukan revisi terhadap Undang-Undang Nomor 13 Tahun 2006 tentang Perlindungan Saksi dan Korban dengan menambahkan ketentuan-kententuan yang mengatur tentang Justice collaborator.

Berdasarkan temuan-temuan hasil pembahasan sebagaimana telah disimpulkan di atas, maka disarankan:

1. Pemerintah dan DPR agar segera membuat suatu kebijakan hukum pidana dalam bentuk UndangUndang atau melakukan revisi terhadap peraturan perundangundangan terkait dalam hal ini Kitab

Urgensi Formulasi Justice Collaborator Sebagai Syarat Perolehan Remisi Bagi Narapidana 
Undang-Undang Hukum Acara Pidana maupun Undang-undang tentang perlindungan saksi yang memberikan pengaturan yang memadai terhadap Justice collaborator dalam peradilan pidana dengan melakukan peninjauan kembali tentang hakikat Justice collaborator secara cermat dan teliti guna menghasilkan suatu peraturan perundang-undangan yang baik sehingga dapat memberikan dayaguna yang maksimal dalam upaya pemberantasan tindak pidana korupsi di Indonesia.

2. Aparat penegak hukum yang menangani perkara tindak pidana korupsi, walaupun hingga saat ini belum ada peraturan perundangundangan yang mengatur secara tegas tentang Justice collaborator, namun kiranya dapat lebih memperhatikan keberadaan Justice collaborator serta dapat memberikan perlindungan yang optimal sehingga keberadaan Justice collaborator dalam peradilan pidana dapat memberikan peran yang maksimal dalam mengungkap tindak pidana dan pelaku utama lainnya dalam jaringan tindak pidana terorganisir.

\section{DAFTAR PUSTAKA}

Buku :

Black., Henry Campbell, 1983, Black's Law Dictionary With Pronounciations, West Publishing Co, St. Paul, Minn.

Danil, Elwi, 2012, Korupsi: Konsep, Tindak Pidana dan Pemberantasannya, Rajawali Pers, Jakarta.

Ghozali., Elizabeth, 2016, Kebijakan Hukum Pidana Terhadap Pemberian Remisi Bagi Narapidana Korupsi
Berdasarkan Tujuan Pemasyarakatan Di Indonesia, "Disertasi", Program Doktor Ilmu Hukum Pascasarjana Fakultas Hukum Universitas Andalas, Padang.

Hamid, Edy Suandi dan Muhammad Sayuti (ed.), Menyikapi Korupsi, Kolusi dan Nepotisme di Indonesia, Aditya Media, Yogyakarta.

Hartono, Sunaryati, 1994, Penelitian Hukum di Indonesia Pada Akhir Abad ke 20. Alumni, Bandung.

Humas LPSK., 2012, Buku Potret Saksi dan Korban dalam Media Massa Tahun 2011, Lembaga Perlindungan Saksi dan Korban (LPSK), Jakarta.

Semendawai, Abdul Haris, 2013, Eksistensi Justice Collaborator dalam Perkara Korupsi Catatan tentang Urgensi dan Implikasi Yuridis atas Penetapannya Pada Proses Peradilan Pidana, (Makalah disampaikan dalam Stadium General Fakultas Hukum Universitas Islam Indonesia, Jogjakarta, 17 April 2013).

Soekanto, Soerjono dan Sri Mamudji., 2015, Penelitian Hukum Normatif, Suatu Tinjauan Singkat, Penerbit Rajawali, Jakarta.

Soemitro, Ronny Hanitijo,1995, Metodologi Penelitian Hukum dan Jurimetri, Ghalia Indonesia, Jakarta,

Suharirizal, Elizabeth Ghozali, 2018, Remisi untuk Koruptor, PT Rajagrafindo Persada, Jakarta.

Webster., A. Marriam, 1985, New International Dictionary, G\&C Marriam Co. Publishers Springfield Mass, USA.

Urgensi Formulasi Justice Collaborator Sebagai Syarat Perolehan Remisi Bagi Narapidana Korupsi di Indonesia 


\section{Website/internet :}

Jaringan Advokasi untuk Whistleblower, Mengadili

Whistleblower, diakses dari http://elsam.

or.id/catatan_hukum_revisi.doc

Kompas, Kedudukan "Whistle Blower" Perlu Diperkuat, diakses dari http://cetak.kompas.com/read/201 0/06/08/02592451/kedudukan.wh istle.blower.perlu.diperkuat.

Sentra Informasi dan Data untuk Anti Korupsi, "Whistle Blower" Belum Terlindung, diakses 2010 /06/08/ dari http:// infokorupsi.com/id/korupsi.php?a $\mathrm{c}=8235 \& \mathrm{l}=$-belum-terlindung.

Semendawai, Abdul Haris, Penanganan dan Perlindungan 'Justice Collaborator' dalam Sistem Hukum Pidana di Indonesia, diakses dari http://www.elsam.or.id/downloads /1308812895_penanganan_dan_pe rlindungan_justice_collaborator

\section{Peraturan Perundang-undangan :}

Undang-Undang Dasar Negara Republik Indonesia Tahun 1945.

Undang-Undang Republik Indonesia Nomor 12 Tahun 1995 Tentang Pemasyarakatan, Lembaran Negara R.I. Tahun 1995 Nomor 77 dan Tambahan Lembaran Negara R.I. Nomor 3641.

-------., Nomor 31 Tahun 1999 tentang Pemberantasan Tindak Pidana Korupsi, Lembaran Negara R.I. Tahun 1999 Nomor 140 dan Tambahan Lembaran Negara R.I. Nomor 3874.

-------., Nomor 20 Tahun 2001 tentang Perubahan Atas Undang-Undang Nomor 31 Tahun 1999 tentang Pemberantasan Tindak Pidana Korupsi, Lembaran Negara R.I Tahun 2001 Nomor 134.
Peraturan Pemerintah Nomor 99 Tahun 2012 tentang Perubahan Kedua atas Peraturan Pemerintah Nomor 32 Tahun 1999 tentang Syarat dan Tata Cara Pelaksanaan Hak Warga Binaan Pemasyarakatan, Lembaran Negara R.I. Tahun 2012 Nomor 225 dan Tambahan Lembaran Negara R.I. Nomor 5359.

Keputusan Presiden Republik Indonesia Nomor 174 Tahun 1999 tentang Remisi, Lembaran Negara R.I. Tahun 1999 Nomor 223.

Peraturan Bersama Peraturan Bersama Menteri Hukum Dan Hak Asasi Manusia Republik Indonesia Jaksa Agung Republik Indonesia Kepala Kepolisian Negara Republik Indonesia Komisi Pemberantasan Korupsi Republik Indonesia Ketua Lembaga Perlindungan Saksi Dan Korban Republik Indonesia Nomor: M.HH - 11.HM.03.02.th.2011; Nomor: PER - 045/A/JA/12/2011; Nomor: 1 Tahun 2011; Nomor: KEPB - 02/01 - 55/12/2011; Nomor: 4 Tahun 2011 tentang Perlindungan terhadap Saksi Pelapor, Saksi dan Saksi Pelaku Bekerjasama.

Urgensi Formulasi Justice Collaborator Sebagai Syarat Perolehan Remisi Bagi Narapidana 